\title{
Short Analysis of the stakeholders' benefit and satisfaction about Rural Land Share Cooperatives of the Southern Jiangsu Province
}

\author{
- A Case Study of Jinxi Town, Kunshan City \\ Yi LI*, Shanghai Tongji Urban Planning\& Design Institute Co.Ltd; China \\ Xihua ZHU, Jinxi Town government; China
}

\begin{abstract}
The agricultural land around Shanghai is famous for its huge population and intensive cultivation. With the expansion of the metropolis, a large number of agricultural people have entered the city to work, and rural land has been abandoned ${ }^{1,2}$. In 2009, Kunshan City implemented a land transfer system, and 99\% of the cultivated land was packaged for large-scale farmers, and initially realized large-scale operation ${ }^{3}$. However, the large-scale business model has gradually experienced problems such as predatory management, ecological destruction, and no sense of social responsibility. Through the establishment of agricultural land share cooperatives, Changyun Village took the lead in realizing the collective management of agricultural land, taking shares in the land, giving priority to paying dividends to the land, and paying wages to the farmers working in the cooperative. The peasants' enthusiasm for entering the city has become an important buffer for the migrants to work in Shanghai and surrounding villages ${ }^{4}$. It has increased the employment rate. At the same time, it has supplied green agricultural products to the city, passed on agricultural technology, and activated local communities.

This article intends to analyse the correlation between several village share cooperative models based on Changyun Village and the large family farm contracting model of more than ten villages, and the satisfaction of villagers, combined with property rights theory, scale economy theory, and accounting cooperatives. Cost-benefit, evaluate the effect of "long cloud-style" collectivization on revitalizing the surrounding villages of metropolises and assess the satisfaction of governments at all levels. Through field interviews and questionnaire surveys, the correlation analysis of village cadres and villagers' satisfaction was conducted.

The government is optimistic about the role of the "long cloud model" in grassroots management and improvement of people's livelihood. Even if public finances are required to invest a large amount of money, it is necessary to strengthen the medical and social security of the villagers. The government is also quite satisfied with the Changyun model. At present, the economic benefits of the stock cooperatives have steadily increased. Although the growth rate is not large, the villagers have a strong sense of well-being, and the village's ecological environment has been improved. In the future, the cost of the village will be reduced after the large-scale operation, and the overall economic benefits will be improved. The
\end{abstract}


future research direction will be how to solve the specific problems that plague the cooperative's production and operation, such as low rice prices and lack of high value-added finishing facilities to continue to activate the surrounding areas of the metropolis and improve the satisfaction of the government and villagers.

\section{Keywords}

Countryside around metropolis, Rural revitalization, Large-scale agriculture, Collective management

\section{Agricultural land cooperatives}

\subsection{The definition of land cooperative}

Agricultural land joint-stock cooperative is made by who enjoy the right to the contracted management of rural land and farmers engaged in agricultural production and operation of collective organizations, such as the management of land investment, entrust DaiGeng circulation mode of centralized and unified planning, unified management of the rural mutual cooperative economic organizations (hereinafter referred to as land cooperative). Since the household contract responsibility system, China's agricultural land is mostly decentralized management. In 1987, China put forward that where conditions permit, land management on an appropriate scale can be steadily promoted. In October 2008, the communist party of China (CPC) stated: "farmers are allowed to transfer their contracted land management rights in the form of subcontracting, leasing, exchanging, transferring and joint-stock cooperation in accordance with the principle of voluntary compensation in order to develop diversified scale operations." This provides a theoretical basis for the establishment of specialized farmer cooperatives based on the pricing of land contracting and management rights. The land transfer began to speed up after China made it clear that "farmers are allowed to transfer their contracted land management rights".

\subsection{The causes of land cooperatives}

Rural land joint-stock system reform comes into being in accordance with the development conditions of rural economy and society. With the development of China's industrialization and urbanization, the household land equalization system based on the land contract responsibility system is facing more and more problems.

In economically developed areas, rural labor transfer to the town and non-agricultural industry, farmers farming will reduce, even some villages have per capita arable land area is small, low degree of intensive land use, the efficiency is not obvious, and some are willing to engage in farming the land farmers and foreign individuals and enterprises need enough land scale management, land circulation strong demand, so the government issued documents, encouragement policy and related supporting policies to promote land scale. As an innovative mode of land transfer, rural land stock cooperative system has been actively responded and promoted by farmers and the government. The reform experiment of rural land joint-stock cooperative system was first carried out in Nanhai, Guangdong province in the 1980s, and then developed to a certain extent in Jiangsu and other places. The south China sea model and Kunshan model came into being in the actual work. 


\section{Basic information of Jinxi town and Changyun village}

\subsection{Subheading 2.1}

Kunshan is located in the Southern Jiangsu, which is economically developed, highly urbanized and has a leading land transfer speed in China. With the expansion of the metropolis, a large number of agricultural population have been to cities for work and rural land is facing the risk of being abandoned. In 2009, Kunshan city implemented the land transfer system. The transfer land is up to more than 200,000 mu. All villages in Jinxi town have set up land joint-stock cooperatives, which have contracted out 15,315 mu of farmland to 127 large professional farmers, covering $99 \%$ of the town's total farmland. The large-scale farmland operation has been initially realized, which has solved the problems of land fragmentation and small-scale agriculture to some extent, and promoted the land intensification and agricultural mechanization degree.

Changyun village is a typical agricultural village, located in the north of Jinxi town. It has thousands of mu of farmland, and a large number of fish ponds. It has 6 natural villages, with 530 residents and 1,780 registered population, covering an area of 3.5 square kilometres. The disposable income of permanent residents is 29,000 yuan per person (2019).

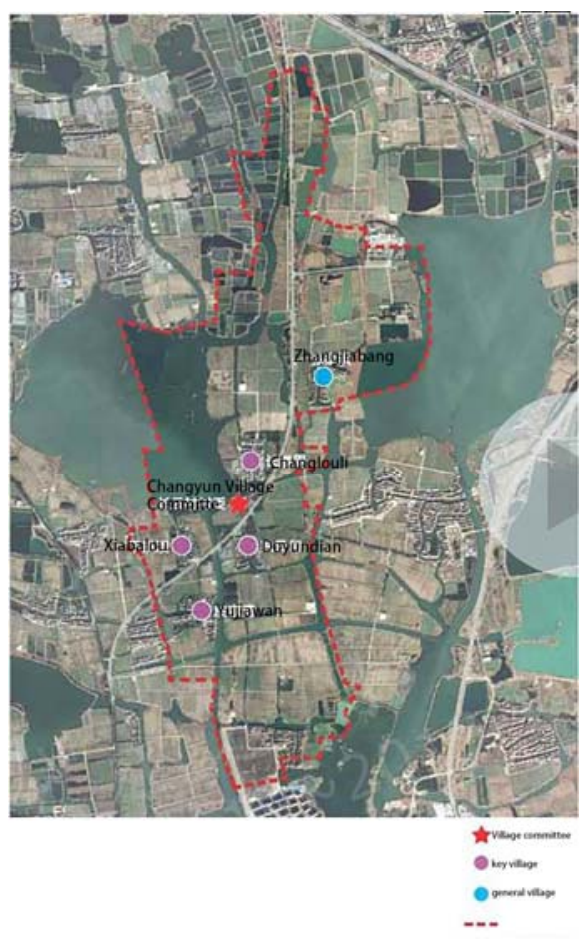

Figure 1 Area of Jinxi Town 


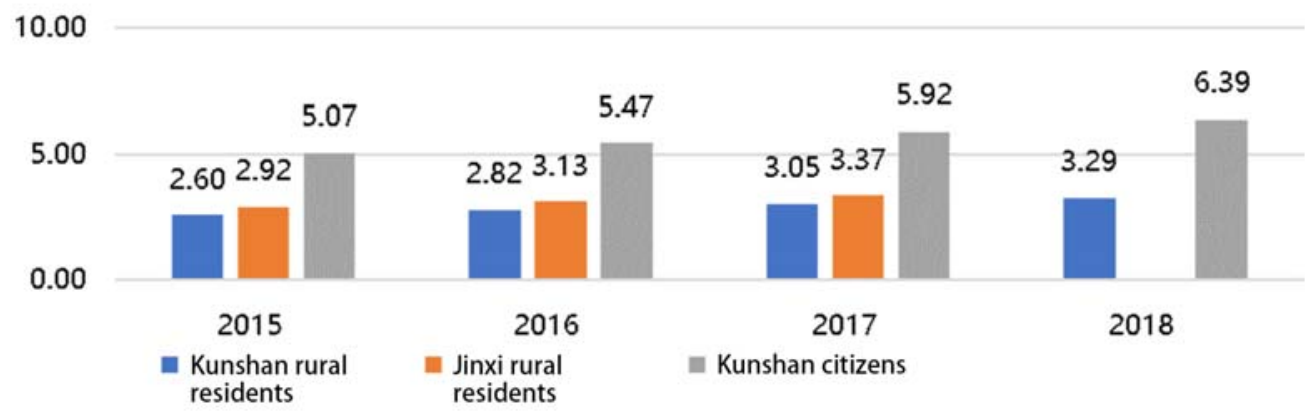

Figure 2 Kunshan urban and rural residents and Jinxi rural per capita disposable income from 2015 to 2017 (ten thousand yuan)

\subsection{Subheading 2.2}

In this research on Jinxi town, we found that the aging degree of rural population in Jinxi town is relatively serious. There is income gap between urban and rural areas. Young adults gather in cities and old people stay in villages. The elderly account for about 30 percent of the farmers surveyed, which is higher than the aging level of the surrounding urban population. The average age of the sampled changyun villagers was 55. Among the rural elderly interviewed in Jinxi town, 50\% live alone or live with their spouses, while half of the surveyed families are 3-6 people, and the younger generation lives in other places. Most of the young and middle-aged people working in the area are outsiders. The population engaged in agriculture is aging.

\section{Average age of villagers}

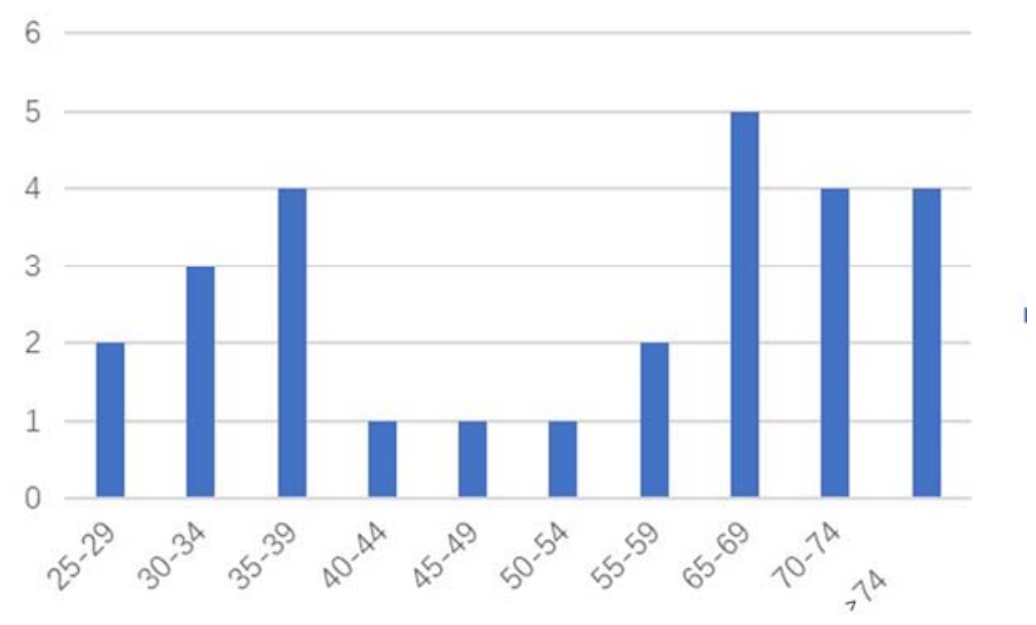

Figure 3 Average age of villagers 


\section{who to live together}

- Live with their children

- Live by themselves

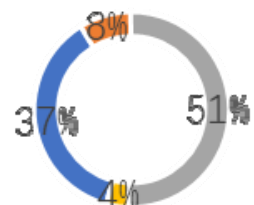

- Live with their grandchildren

others

Figure 4 who to live together with villagers

\section{Changyun Agricultural land cooperative}

\subsection{Subheading 3.1}

In 2009, Changyun village gave land to 8 large farmers, and the rest farmers received a circulation income of 700 yuan/mu. Problems such as predatory operation, ecological destruction and no sense of social responsibility gradually appear in the large family management model, which leads to the widening gap between the rich and poor in the village. The government's subsidies to farmers for growing grain have risen gradually, to the point that they are equivalent to rental payments, while farmers who have transferred their land have not received dividends. Many large farmers sublet their farmland to earn the price difference. Large families disregard social responsibility, and perfunctory or even resistance to instructions such as pesticide safety, environmental protection, water conservancy and other, Leading to the pesticides disorderly and ecological damage.

Changyun village takes villages and towns as units and turns the traditional large contract into the farmland stock cooperative. In 2009, it established the Changyun agricultural land share professional cooperative (hereinafter referred to as the agricultural land cooperative). The agricultural land cooperative has been registered for industry and commerce, engaged in agriculture, forestry, its registered capital is 7.31 million yuan (2019). Cooperatives adopt the corporate system of operation and management, and farmers become shareholders with their contracted farmland rights and enjoy dividends. Changyun village tries to "co-own, co-manage and co-enjoy", and adopts the new mode of "cooperative farm" such as collective operation, contract labour and fixed production. Farmers' income mainly comes from dividends and labour in cooperatives.

Currently, about 1900 mu of rice is planted in Changyun village. In 2019, the farmland cooperative cultivated $1,850 \mathrm{mu}$. As a pilot project of collective agricultural cooperative operation in the town, Changyun farm launched innovative practice and promoted agricultural modernization and intensification in combination with Jinxi town's "10,000 mu of good farmland" project. At the same time, the development of ecological agriculture, raising rice paddy duck, rice paddy crab. 


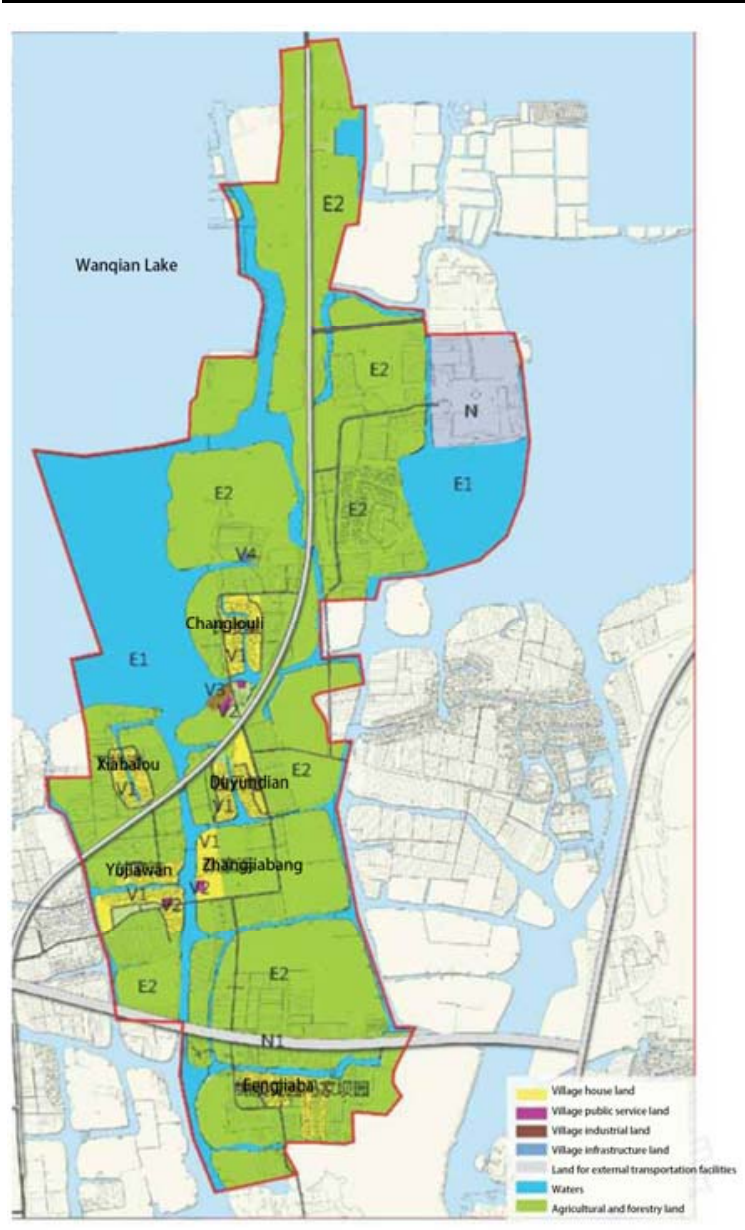

Figure 5 Agricultural Land of Jinxi Town

\section{The model of Changyun land cooperative}

\subsection{Profit distribution of agricultural land cooperative}

Cooperative dividends include two parts: Guaranteed income + dividend income. The form of guaranteed minimum income is the most suitable distribution form of land joint-stock cooperatives.

The first dividend is the farmland guaranteed income distributed to the shareholders at the beginning of the year, which is 900 yuan per mu per year. The second dividend is paid at the end of the year, which is no less than 100 yuan per share.

\subsection{Production mode of agricultural land cooperative}

1) scale and standardization

The cooperative carried out reclamation, building contiguous high-standard farmland. Improve soil quality through fallow cultivation and ecological transformation. With rice, oilseed rape, wheat, barley, highland barley and other crops as the key, the planting structure is optimized. 
Farmland joint-stock cooperatives coordinate the allocation of capital, technology, labor force, land and other production factors, realize centralized support of agricultural technology services, unified seed supply, unified fertilizer use, unified disease prevention and pest control, unified field management, and unified settlement; We will implement centralized management of agricultural production, and settle production costs, operating expenses, subsidies for policy funds and production benefits.

2) Contractor's Scheduled Production Village collective and experienced farmers signed a contract production responsibility, every 100-200 mu to hire experienced farmers as administrators, awards for overproduction and compensation for reduced production. If more workers are required, the cooperative arrange villagers to do farm work. At the end of the year, farmers receive their wages by work record.

\section{The cost-benefit analysis of stakeholders}

\subsection{Cost-benefit analysis of Jinxi town, Kunshan city}

Tangible cost of government:

The cost of Jinxi town and Kunshan city mainly comes from land subsidies, water conservancy investment, agricultural tools support, technical support and so on.

Local government finance has supported land transfer. Since the 21st century, the investment of modern agriculture at Suzhou and county levels has been more than 2 billion yuan every year. Land about 15,400 hectares, equivalent to $231,000 \mathrm{mu}$, an average of 26.58 million yuan per mu. Changyun village irrigated area is a key construction project of Jinxi irrigation and water conservancy, which has invested 28 million yuan to transform the irrigated area of 5,000 mu of farmland. Now the village has formed a contiguous irrigated area, and the mechanization degree has been further improved. Jinxi Changyun irrigation district has built "one body and two wings" water conservancy technology information application platform. Jinxi has established a long-term water management and protection mechanism for small farmers. At the same time, the higher government needs to carry out technical promotion and scientific research support. These constitute tangible costs.

Intangible benefits of government:

The government's grass-roots construction income is the largest intangible income. It is reported that Changyun village's cadre and mass communication is closer, the degree of mass participation in management is strengthened, and party members' sense of responsibility is also increased. Villages have increased farmland and increased the balance of occupied and subsidized land. The government promoted agricultural techniques and trained more talents familiar with practical agricultural techniques. Provide members with free technical and professional training. The governments of Kunshan city and Jinxi town think highly of the role of "Changyun model" in grass-roots management and improvement of people's livelihood, and take it as a model to promote.

\subsection{Cost-benefit analysis of Changyun Village}

Tangible benefits:

Total village income has increased. 
At the village collective level, the costs include land transfer payment, agricultural labor settlement compensation, and the purchase of tools and tools seeds. Expenditure: 1.87 million yuan for rice and 450,000 yuan for wheat. Before 2012, the total income of Changyun village was less than 1 million yuan, which is a relatively weak village in jinxi town of Kunshan. Cultivated land area: 1,850 mu. Jinxi ecological rice planted in the irrigated area was rated as "the ten most popular real estate rice by Suzhou people". It was mainly sold to Jinxi town and Kunshan city with a market price of 9.8 yuan $/ \mathrm{kg}$.

In terms of income, the total revenue was 2.9 million yuan, based on the per mu yield of $1,000 \mathrm{jin}$ of rice and $600 \mathrm{jin}$ of wheat. In terms of expenditure, the planting cost of rice and wheat, the service fee of labor and agricultural technology per mu and the payment of circulating gold amount amount to about 1 million yuan. Total revenue minus total cost, the net balance is about 500,000 yuan. If the contract is contracted by a large family, 300 yuan/mu will be paid according to the contract, which is only 100.2 million yuan. By contrast, the net operating income of "cooperative farm" has increased by 194,100 yuan.

The intangible benefit is the improvement of ecological environment. The sanitary environment of changyun village has been improved, the village capacity environment, the appearance of farmland has been increased, and pesticide has been applied.

\subsection{Cost-benefit analysis of Villagers}

Intangible costs:

Opportunity cost of farmer: working income is measured and calculated.

Land is not only a means of production, but also a means of living. After the transfer of land, farmers cannot grow their own vegetable seasonings, but need to buy them. Field research found that many people were growing vegetables at the head of the village. Manpower liberation: expand the scale of operation, farmland concentration area is conducive to mechanized operation, is conducive to the efficient use and liberation of labour force, help farmers go out to work.

The increase of cooperative income can bring the income of farmers who have become shareholders. The land transfer fund increased from 750 yuan per mu in 2012 to 1050 yuan per mu in 2015, an increase of $40 \%$. Farmers transfer income steadily. Before 2012, the village's per capita income was less than 20,000 yuan. Some 50, 60 personnel, through participating in the demonstration of agricultural labour settlement compensation, the annual salary can increase about 20,000 yuan. The per capita income of villagers increased from 21,000 yuan/person in 2012 to 29,000 yuan/person in 2015, an increase of $36 \%$. 


\section{The satisfaction of villagers}

\subsection{The fieldwork analysis to satisfaction of Changyun's villagers}

\section{Farmers' satisfaction with dividends of cooperatives}

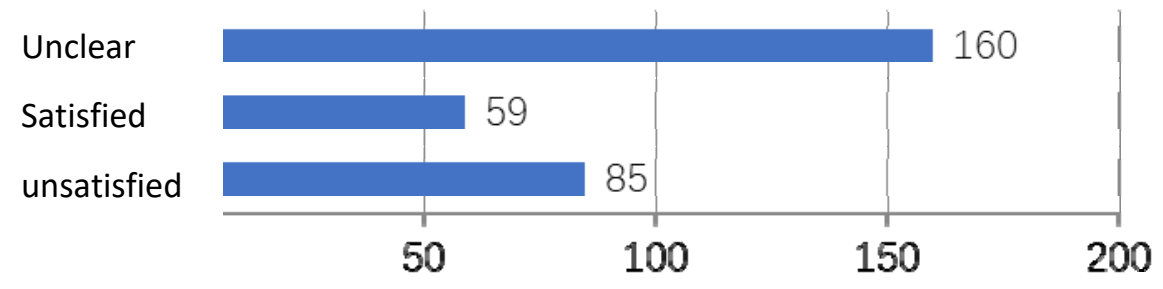

Figure 6 Farmers' satisfaction with dividends of cooperatives

\section{The reason for Farmers' unsatisfaction}

Other

Unfair distribution

Low land management efficiency

with dividends

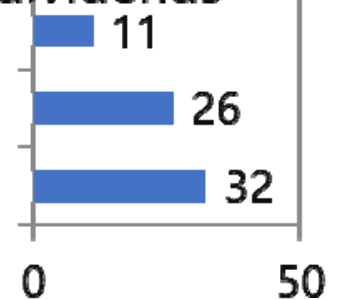

Figure 7 The reason for Farmers' unsatisfaction with dividends

Farmers in Changyun village are more satisfied with the dividends of the cooperative than those in Kunshan city. $18 \%$ are dissatisfied with the dividends of the cooperative, $19 \%$ are satisfied, 52\% avoid answering questions directly and choose unclear, and the remaining $11 \%$ do not choose.

The main reasons for low satisfaction are the land management efficiency and distribution fairness. The villagers also suggested improving the quality of their produce.

\subsection{How to increase returns}

Jinxi agricultural products sales market is small in number and scale, and no well-known consumption place has been established. Comparing with the surrounding areas of Yangcheng lake, it can be found that the professional market and comprehensive market in Jinxi town, as well as the catering places for consuming agricultural products, are far less than Yangcheng lake area. The high value-added industrial chain did not come into being in this town. Most of the primary industries in Jinxi village produce raw materials with less primary processing and lower added value.

In the main functional area planning, Jinxi town belongs to east China grain and oil production area, so it can develop characteristic aquatic products. Changyun cooperative is 
also doing shrimp farming in rice paddies and crab farming in rice paddies. Increase the added value of farmland. Deep processing of grain can be considered to explore the value of farmland. Build your own rice processing plant, but no land and no money. Village officials hope to build a centralized rice processing plant in Jinxi. The cooperative develops rice paddies to raise fish, shrimp and crabs, and resells them after processing outside. It needs technical guidance and training.

\subsection{A brief analysis of the risks associated with earnings:}

Increased risk of scale operation

With the deepening of land circulation and the concentration of agricultural production factors including land, capital, technology and labor, the rights and interests of village collectives and farmers have also entered the production and operation entities of agricultural enterprises in the form of shares. However, agricultural production faces the dual pressure of natural risk and market risk. Cooperatives should enable farmers to participate more actively in management and be more aware of risks.

Production risks faced by Changyun cooperative include: low quality and low price of rice brand. Second, although agricultural products have brands, there is still room for improvement in quality. We hope to give priority to improving the quality of agricultural products. Changyun village also faces management risks. The Changyun model relies on strong village cadres. The management sustainability of the Changyun model still needs to be explored. The long-term disadvantages of agricultural land cooperatives have not been shown yet, but the risks in the future are also worth paying attention to. Precedent has been set in Nanhai, Guangdong, and equity distribution has solidified and caused conflicts. The village committee and the joint stock company are identical, the financial income and expenditure lacks the supervision. Villagers lack information and professional experience, making it difficult to express their demands

\section{Conclusions}

The land stock cooperative system imitates a company, but its nature is different from that of a company. The people who make up the joint-stock system of land are local villagers. But also assume the function of food security, social harmony and stability resettlement of farmers, rural construction function. As can be seen from Changyun cooperative, rural migrant workers in cities have volatility. The cooperative has become an important buffer for migrant workers in Shanghai and surrounding villages, increasing the employment rate, providing green agricultural products, inheriting agricultural technologies and activating local communities. The advantage of cooperative is that it is convenient to introduce capital and profit distribution, which can promote the large-scale operation of agricultural land, and it is suitable for areas with deep industrialization and urbanization. In terms of equity distribution and agricultural production efficiency, cooperatives still need to be improved. Faced with fierce market competition, cooperatives mainly composed of middle-aged and elderly people left behind are not profitable, but they have their applicability and advantages, which can bring certain benefits to grass-roots governments, villages and villagers, and need to be promoted according to local conditions. 


\section{References}

Wu, Fulong, Fangzhu Zhang, and Chris Webster, eds(2013) Rural migrants in urban China: enclaves and transient urbanism. Routledge,

Han, Sun Sheng(2000) "Shanghai between state and market in urban transformation." Urban Studies 37.11 (2000): 2091-2112.

Yun, Jin Xiongbing Pu Lijie Luo, and Peng Buzhuo.(2003)"LAND USE AND LAND COVER CHANGE AT COUNTY LEVEL_-A CASE STUDY OF KUNSHAN CITY [J]." Soils 3 (2003): 5.

Croll, Elisabeth J., and Huang Ping.(1997)"Migration for and against agriculture in eight Chinese villages." The China Quarterly 149 (1997): 128-146. 